\title{
Peter De Cupere' nin Sanatında Bir İfade Biçimi Olarak Koku
}

\author{
Scent as a Form of Expression in the Art of Peter De Cupere
}

\section{Mine DEĞİRMENCİ AYDIN1}

\author{
Araştırma Makalesi / Research Article \\ Geliş Tarihi / Received: 07. 02. 2021 \\ Kabul Tarihi / Accepted: 09. 05. 2021 \\ Doi: 10.48146/odusobiad.876125
}

Atıf / Citation: Değirmenci Aydın, M. (2021), “Peter De Cupere’ nin Sanatında Bir İfade Biçimi Olarak Koku” ODÜSOBİAD 11(2), 403-416, Doi: 10.48146/odusobiad.876125

\begin{abstract}
Öz
Batı dünyasında kokunun, görme ve ișitme duyularıyla kıyaslandığında uzunca bir süre göz ardı edilmiș olduğu açıktır. 20. yüzyılın başında İtalyan Fütürist ressam Carlo Carra'nın 1913' te yayınladığı "The Painting of Sounds, Noises and Smells", Seslerin, Gürültülerin ve Kokuların Resmi", manifestosuyla kokunun sanata dahil olmaya başladı̆̆ı söylenebilir. Duchamp’ın, 1938 yılında Paris'te düzenlediği Uluslararası Sürrealist Sergisi'nin de; kokuyu temel alan, kavrulan kahve kokusuyla doldurduğu mekân, koku sanatını tanıtmak için avangard bir girişim olarak kabul edilebilir. Duchamp'ın yolunu açtı̆̆ı koku sanatı, 1960’lı yıllara gelindiğinde, Fluxus ve Arte Povera gibi hareketlerin içinde yerini almıștır. Jean-Michel Othoniel, Wolfgang Laib, Mario Merz, Valeska Soares, Joseph Beuys gibi sanatçıların kükürt, balmumu, yağ vb. kokulu doğal malzemeleri çalışmalarında kullandığı görülmektedir. 20. ve 21. yüzyıllarda önceleri çoğunlukla tıp ve psikoloji alanında ilgilenilen kokunun, giderek antropoloji, sosyoloji, tarih ve sanat alanlarında da ilgi odağı haline geldiği görülmektedir. Ayrıca gizemli yapısıyla kokunun, popüler, teknolojik ve akademik çalışmalarda da dikkat çektiği görülür.

Çalışmada; 2014 yılında Olfactory Art manifestosunu yazan akademisyen sanatçı Peter De Cupere'nin sanatında bir ifade biçimi olarak kokuyu nasıl ele aldığı, sanatçının heykel, resim, enstalasyon, video, performans vb. çeşitli mecralardaki üretimleri üzerinden irdelenmiștir. Sanatçı kokunun da, tıpkı fotoğraf, ses ve video gibi görsel sanatlara entegre edilmesi gerektiğini, böylece koku sanatının yeni bir sanat hareketi olarak kabul görebileceği ve sanatın -izmlerine Olfactism olarak eklenebileceğini, kokunun bağlam olduğu veya bağlam sağladığı sürece sanat eserleriyle ilgili olduğunu, temsilinin mümkün olabileceğini iddia etmektedir. Çalışmada alan yazını incelendiğinden doküman analizi yöntemi kullanılmış, bu yöntemle elde edilen verilerin içerik analizi yapılmıştır. Özel bir alanı kapsayan araştırmada daha çok sanatçının öz kaynakları üzerinden elde edilen bulguları değerlendirilmiş ve eserleri çözümlenmiştir. Sanatçıya ait sanatsal uygulamalarda koku faktörü incelenmiş ve kokunun kimi çalışmalarda yardımcı bir öge olarak yer alırken, kimi çalışmalarda içeriğin kendisine dönüştügü görülmüştür.
\end{abstract}

Anahtar Kelimeler: Heykel, Koku sanatı, Koku, Olfactory art, Peter De Cupere.

\begin{abstract}
It is clear that in the Western world, smell has been ignored for a long time compared to the senses of sight and hearing. At the beginning of the 20th century, with the manifesto of "The Painting of Sounds, Noises and Smells, Picture of Sounds, Noises and Smells", published in 1913 by the Italian Futurist painter Carlo Carra, it can be said that scent began to be included in art. In the International Surrealist Exhibition organized by Duchamp in Paris in 1938; the exhibition, which is based on smell and filled with the scent of roasted coffee, can be regarded as an avantgarde attempt to promote the art of fragrance.

The art of fragrance that Duchamp paved the way, took its place in movements such as Fluxus and Arte Povera in the 1960s. It is seen that he uses scented natural materials in his works. As of the 20th and 21st centuries, it has been observed that the scent, which was mostly focused in medicine and psychology, has become the center of attention in the fields of anthropology, sociology, history and art. In addition, with its mysterious nature, it is witnessed that the scent attracts attention in popular, technological and academic studies.
\end{abstract}

${ }^{1}$ Dr. Öğr. Üyesi, Ordu Üniversitesi Güzel Sanatlar Fakültesi Heykel Bölümü, Ordu, minedeirmenci@gmail.com:, ORCID ID:00000001-6652-6601 
In the study, the process of scent's becoming a form of expression in the art of academic artist Peter De Cupere, who wrote the Olfactory Art manifest in 2014, was examined through the artist's productions in various media such as sculpture, painting, installation, video, performance. The artist states that scent should be integrated into visual arts, just like photography, sound and video, so that scent art can be accepted as a new art movement and can be added to its -ism as Olfactism. He also claims that fragrance is related to works of art, as long as it is context or provides context, where representation is possible. In this work, document analysis technique has been used because the body of literature has been examined; accordingly, the content of the data that has been gathered by this technique, is analyzed. In the research covering a special field, the findings obtained from the artist's own resources were examined and his works were analyzed. In the artistic practices of the artist, the odor factor was examined and it was seen that while the odor was an auxiliary element in some works, it transformed into content itself in other works.

Keywords: Sculpture, Scent art, Fragrance, Olfactory art, Peter De Cupere.

\section{Giriş}

Koku alma duyusunun, görme, işitme ve hatta dokunma duyusundan bile daha önce etkin olduğunu söylemek mümkündür. Dünyaya yeni gelen bir bebeğin ilk olarak koku aracllı̆̆lyla anneyle temas kurduğu bilinmektedir. İnsanlar için güçlü bir duyu olarak kabul edilen, insanı fiziksel, psikolojik ve sosyal düzeyde etkileyen koku, bu yönüyle duyular içinde başat kabul edilir. Koklama duyusunun, canlıların etrafındaki kimyasallara tepki vermesi bakımından diğer duyularla karşılaştırıldığında daha gelişmiş olduğu görülür. "Görme eylemi, insan gözünde dört ışık duyargası ile dokunma duyusu ise en az dört tür basınç yanında; sıcak, soğuk ve acıyı algılayan çeşitli alıcılara bağlı olarak gerçekleşir. Binin üzerinde alıcısıyla sürekli yenilenen ve alışık olduğumuz kokulara göre değişen bir yapıya sahip olan koku alma duyusu; insanların çok sayıda kokuyu birbirinden ayırmasını mümkün hale getirmiştir" (URL1). Sağlıklı her insan nefes aldığında etrafındaki tüm kokuları duyumsar. Koku duyusunu kaybetmiş insanların ifadelerine bakıldığında yemeklerin tadını alamadıkları gibi hayattaki birçok şeyden de keyif alamadıklarını ifade ettikleri görülmüştür. Koku; fark ettirmeden insan yaşamının arka planını doldurmaktadır ve eksikliği durumunda yaşam kalitesini düşürmektedir.

Antony Synnott tarafından 1988-1991 yılları arasında Montreal Concordia Üniversitesi'nde 270 öğrenci ve öğretim üyesinin katılımı ile bir anket yapılmıştır. Bu ankette katılımcılara sevdikleri ve sevmedikleri kokular sorulur. Yeni biçilmiş çim, gül, ev yapımı ekmek, bebek kokusu vb. kokular sevilen kokular arasında yer alırken; ter kokusu, benzin, domuz çiftlikleri, tavuk kümesleri, sigara dumanı, hastaneler, çiğ et ve bazı parfüm kokularının sevilmeyen kokular arasında yer aldığı görülmüștür. Katılımcılardan bazıları parfüm kokusunun kendilerini hapşırttığını, ani baş ağrısı yaptığını ve mide bulantısına neden olduğunu dile getirmişlerdir. Araştırmada ayrıca katılımcıların kokulara duygusal tepkiler verdiği de gözlenmiş, iyi anıları çağrıştıran kokuların insanları neșelendirdiği gözlenirken; buna karşın kötü anıları çağrıştıran kokuları ise insanların tiksintiyle ve yüzlerini burușturarak karşıladığı gözlemlenmiștir. Anılarla olan bu güçlü bağlantının güzel kokan bir çiçek kokusunun bile katılımcıların üzülmelerine ve ağlamalarına sebep olduğu görülmüştür. Yapılan bu anket çalışmasında, kokuların duyusal ve duygusal yaşamlarımız için önemli olduğu ve kokunun bilinçsizce, insanlar tarafından kayıt altına alındığı kabul edilmiştir (Classen, vd., 2003:1,2).

Kokular üzerine araştırma yapan Vedat Ozan Kokular Kitabı'nda bilim insanlarının bütün kokuların başlangıçta nötr olduğunu söylediklerini, kokuyu olumlu olumsuz şeklinde sınırlandırmamızın nedeninin o kokunun ilk duyulduğunda ruh haliyle ilişkili olarak gelişmiş bir durum olduğunu dile getirdiklerini aktarmaktadır. Limbik sistemle olan dolaysız ilişkisinin, insanın ruh halini etkilediğini ve geri dönüşlerin her zaman yoğun duygu içerdiğini belirtmektedir (Ozan, 2020:250, 252).

Linda Solay (2012) Scent in Contemporary Art: An Investigation Into Challenges \& Exhibition Strategies başlıklı yüksel lisans tezinde koku sanatının başlıca zorluklarını ve sergileme stratejilerini araştırmış, güncel yaklaşımlar geliştirmeye çalışan sanatçlar için etkili sergileme yöntemleri konusunda incelemeler yapmıștır.

Kokunun bir ifade aracı olarak Görsel Sanatlarda kullanılmasından hareketle bu çalışmada; kendini kokularla çalışan görsel sanatçı olarak tanımlayan, akademisyen sanatçı Peter de Cupere'nin kokuyu temel alarak 2003-2018 yılları arasında ürettiği sanatsal çalışmalarından farklı disiplinlere ait yapıt örnekleri incelenmiştir. Sanatçının resim, heykel, enstalasyon, video, performans vb. çeşitli mecralarla bir araya getirdiği kokunun, sanat yapıtına sağladığı katkı ve alımlayan üzerinde nasıl 
etkiler yarattığı, hafıza ve anılarla olan ilişkisinin nasıl gerçekleștiği sorularına eser analizleri üzerinden yanıtlar aranmıştır. Konuyla alakalı literatür taraması yapılmış, koku sanatı üzerine Türkçe kaynaklarda az sayıda akademik çalışmaya rastlanmıştır. Yeni medyumların alana kazandırılması anlamında sanatçı üzerinden incelenen koku olgusunun alana katkı sağlayacağı düşünülmektedir. Yapılan araştırmalar doğrultusunda koku sanatının alımlayan açısından yeni deneyim alanları yarattı̆̆ ve hafızayla yakın ilişki içinde olduğu görülmüştür. Çalışmada nitel araştırma yöntemlerinden doküman analizi yöntemi kullanılmış, alan yazını incelenmiş, özellikle sanatçının kendine ait web sitesi ve verdiği röportajların ışığında elde edilen verilerin içerik analizi yapılmıştır.

\section{Bir Fenomen Olarak Koku}

İnsanın koku alma duyusunun hayvanlarla kıyaslandığında, zaman içerisinde zayıfladığı ve köreldiği görülmüştür. Açılanması oldukça zor bir fenomen olan koku, renkler gibi isimlendirilemez. "Kokular, tatlar kadar kolay ayırt edilemediklerinden adlarını nesnelere borçludurlar" (Aristotales, 2011: 112). İnsanların kokuyu açıklamak için bazı metaforlara başvurdukları görülür. Koku alma duyusu renkten oldukça etkilenir. Örneğin bir çilek şurubu ne kadar kırmızıysa o kadar çok çilek kokar ve kahve, kahverengi bir paket içerisinde olduğunda daha keskin koku yayar. İnsanlar güçlü kokuları koyu renklerle özdeşleştirirken; diğer taraftan açık renkli ürünleri hafif kokularla özdeştirmişlerdir (Causse, 2019: 84,85).

Kokuya kültürel yaşantı içerisinde baktığımızda, dile yansımasının genellikle olumsuzluk içerdiği görülmüştür. Diğer duyulara yapılan “keskin gözlü” "vizyoner” “iyi bir kulağa sahip” (URL2) gibi övgü içeren kalıplara benzer söylemlerin olmadığı gibi; olumsuzluk içeren "burnunu sokmak" ve "kokusu çıkmak" gibi birkaç deyimde varlık gösterdiğini söyleyebiliriz.

Koku, kültür tarihi boyunca farklı kullanım alanlarına sahip olmakla birlikte en derin işlevini mistik/dini ritüellerde göstermektedir. Derin psikolojik etkileriyle, öte dünya geçişlerini kolaylaştıran ve bedenin ruh ile kutsal bir dengeye taşınmasında spritüel bir araç olan kokular, bilinç ve bilinçaltı kuvvetlerini eklemleyerek duru görüye açık bir mekân ve yaratıcı zihin süreçleri için bir zemin oluşturmaktadır.

Kokunun tarihine bakıldığında; Platon erotizmi ve fiziksel hazzı çağrıştırdığı için parfümleri kınamıştır. Aromatik kokuların kullanımını fahișelerle bağdaştırırken; erdemli insanların, ruhlarını iyileştirmek için müzik ve matematikle ilgilenmeleri gerektiğini ifade etmektedir. Platon, burnun beyne yakınlığı sebebiyle tüm yasaklanmış duygu ve arzularla temas halinde olduğunu söylemiş, bedeni bütün kokularıyla ruhun geçici mezarı olarak kabul etmiştir. Sokrates, dogmatik bir yaklaşımla kokunun sosyal sınıfı yansıttığını ifade etmiştir; ancak Platon için sosyal ilişkilerde göz ve kulak burundan daha önemlidir ve bu aktiviteler ona göre asildirler. Aynı görüşü paylaşan birçok filozofun da dokunmayı ve koklamayı iğrenç etkinlikler olarak değerlendirdikleri görülmüştür (Classen vd., 2003:4).

On sekizinci yüzyıla kadar geçen süreçte, filozofların koku hakkında ciddi çalışmalarına ve yazılarına rastlanmamıştır. Çağdaş Batı'da kokunun değersizleștirilmesi, on sekizinci ve on dokuzuncu yüzyıllarda gerçekleşen duyuların yeniden değerlendirilmesiyle doğrudan bağlantılı olmuştur. Dönemin filozofları ve bilim insanları görmenin en önde gelen akıl ve medeniyet duygusu, kokunun ise delilik ve vahşet duygusu olduğuna karar vermişlerdir. On sekizinci yüzyllın sonunda Kant ve Hegel estetik ve sanat teorisi söz konusu olduğunda, kokuların ve koku alma duyusunun gerçek sanat eserlerinin veya estetik deneyimlerin temeli olamayacağını iddia etmişlerdir (URL3). Daha sonra Darwin, Freud vb. düşünürler, koku alma duyusunu geri plana itmişler; görme duyusunun önceliğe sahip olduğunu ileri sürmüşlerdir. Kokunun kullanımı antik çağlara dayansa da 17. ve 18. Yüzyıllarda enfeksiyonlar, zihinsel ve fiziksel birçok rahatsızlığın tedavisinde kullanılmıştır. On sekizinci yüzyılın sonu ve on dokuzuncu yüzyılın başlarında, tıpta kokuya olan ilginin arttığı görülmektedir (Classen, vd., 2003:4).

Bilim insanları ve doktorlar; on sekizinci yüzyıl Paris'inde dar sokaklar ve yükselen yapıların, temiz havanın sokaklarda dolaşmasını engellediğini, balıkçı dükkânlarının, kasapların, genç cerrahların anatomi çalışmak için aldıkları kadavra parçalarını attıkları lağımların, mezarlıkların ve evlerde bulunan ayakyolu çukurundan buharla yayılan dışkı kokusuyla birlikte, kiliselerden yayılan mahzen ve küf kokusunun insan sağlığını tehdit ettiğini belirtmişlerdir (Mercier, 2004: 40,41). Buna bağlı 
olarak da, bahsedilen sebeplerden ve havaya salgılanan zararlı gazlardan yayılan veba ve sıtma gibi hastalıkların nedenlerini araştırmışlardır. Duyuların ve kokunun önemiyle ilgili İngiliz ampirizmi, duyuların bilginin kaynağında önem teşkil ettiğini düşünmüş ve deneyimin bilgiye dayanak olmasından hareketle kimyagerler ve doktorları içeren bilim insanlarının araştırmalarında koku da dahil tüm duyuları kullandıkları görülmüştür. Aydınlanma dönemi ve sanayi devriminde de mantık, ilerlemenin motoru olarak görülmüss, duygu ve duyular ötelenerek, koku duyusu da önemsiz kabul edilmiştir. Tüm bilimsel araştırmacılar, filozoflar ve sanatçllar, aydınlanma filozoflarının yaptığı ölçüde rasyonaliteyi vurgulamamışlardır. 18. Yüzyılda Rousseau ve Goethe gibi yazarlar, sezgi ve duygusal katılımın önemine vurgu yapmış, ayrıca kokuya büyük övgülerde bulunmuşlardır. İlerleyen süreçlerde bilim dünyasında hala kokuyla ilgili yoğun bir araştırmanın olmadığı görülmüş̧ür. Işık ve sesin ölçülebilir nitelikte özellik taşıması, koku duyusu için geçerli olmadığından bu durumun araştırmayı güçleştirdiği söylenebilir (URL4).

Koku üzerine araştırmalar yapan Ozan' a göre;

Koku; duygu ve duygu durumumuza hitap ediyor. Hâkim duyu olan görsellikse, düşünce ve anlamayla ilgili. Görüntü bizi nesneden çokça uzaklaştırlyor. Yani resimlerdeki veya fotoğraflardaki görüntüleri bir çerçeve içinde kabul ediyor ve çerçevenin içindekini anlamaya çalışlyoruz ki entelektüel bir tepki verip davranış biçimi geliştirelim. Oysa kokuyu duyduğumuzda böyle bir çerçeve söz konusu değil. Bir anlamda işitme duyusuyla ortak bir paylaşım olarak koku bize çerçevesiz geliyor ve bizi içine alıyor (Ozan,2020: 17)

Marcel Proust'un 1913-1927 yıllarında yayımlanan yedi ciltten oluşan "Kayıp Zamanın İzinde" romanı koku duyusunun hafızayla olan ilişkisini çarpıcı bir şekilde ortaya koymuş, kokunun anıları canlandıran durumu daha sonra Proust etkisi olarak literatüre geçmiştir. Kokunun diğer duyulara göre dolaysız bir şekilde duyumsayanda yarattığı güçlü etki, sanatçıların da ilgisini çekmiş ve böylece koku görsel sanatlar içerisinde yerini almaya başlamıştır.

\section{Koku Sanatı}

Koku, batı dünyasında görme ve işitme duyularıyla kıyaslandığında uzunca bir süre göz ardı edilmiş ve 20. yüzyılın başına kadar sanat dünyasında hak ettiği şekilde varlık gösterememiştir. Koku duyusunun estetik deneyimleri tetikleyebildiği gerçeğinin kabulü zaman almıştır. 1913' te İtalyan Fütürist ressam Carlo Carra' nın yayınladığı "The Painting of Sounds, Noises and Smells" (Seslerin, Gürültülerin ve Kokuların Resmi), manifestosu kokunun sanata dahil edilmesi anlamında büyük önem taşımaktadır. Carra'nın Manifestosu; resimde, çoklu duyusal uyarılmayı yansıtma arzusuyla öncü bir girişim olarak kabul edilebilir. 1920'de Avusturyalı ressam Raoul Hausmann "Presentism (Şimdicilik) Manifestosu"nda "Duyularımızı genişletmek ve fethetmek istiyoruz! Tüm sınırları aşmak istiyoruz !!!" sözleriyle diğer Dadaist sanatçılarla beraber duyusal uyarılmanın yolunu açarak, sanatın sinırlarını zorlayan bir tavır geliştirmiş̧tir (Muller, 2018:99).

Marcel Duchamp'ın, 1938 yılında Paris'te düzenlediği Uluslararası Sürrealist Sergisi'nde; koku temel alınarak, mekân, elektrikli bir mangalda kavrulan kahve kokusuyla doldurulmuştur. Bu eylem koku sanatını tanıtmak için avangart bir girişim olarak kabul edilebilir. 1960'lı yıllara gelindiğinde, Duchamp'ın yolunu açtığı koku sanatı, Fluxus ve Arte Povera gibi hareketlerin içinde yerini almıștır. Jean-Michel Othoniel, Wolfgang Laib, Mario Merz, Valeska Soares, Joseph Beuys gibi sanatçlların kükürt, balmumu, yağ vb. kokulu doğal malzemeleri çalışmalarında kullandığı görülmektedir. Örneğin, 1975 yapımı bir enstalasyonda, Bill Viola, okaliptüs yapraklarını kaynar suya bırakan bir kadının videosunun önüne, keskin kokulu, okaliptüs yapraklarından oluşan bir tencere yerleștirdi; bu, kokuyu görüntüye kıyasla düşünmek için ustaca bir provokasyon olarak değerlendirilebilir. Brezilyalı sanatçı Cildo Meireles'in 1980 tarihli bir çalışmasında ziyaretçilerin, masa üzerinde tek bir mumun yandığı karanlık bir odaya girmesi sağlanır ancak aynı zamanda odanın her an patlayabileceğini düşündüren doğal gaz kokusuyla izleyicinin üzerinde bir alarm yarattığı görülmektedir (URL5).

Postmodernizmin kendini iyiden iyiye hissettirmesiyle 1980'li yıllarda, görsel paradigmanın zayıflayıp, diğer duyuların etkinleştiği; ayrıca, kadınların, batı dışı yerel geleneklerin varlık gösterdiği yıllardır. Bu durum, duyusal estetik yelpazesinin daha geniş bir alana yayılmasına neden olmuştur. Postmodernizm, görsel ve metinsel olmayan, ruh hali ve atmosfer yaratan fenomenleri ön plana çıkarmıştır. Ayrıca bienallerin dünya çapında farklı kültürlerin duyusal deneyimlerinin çeşitlenmesinde önemli katkılar sağladığı görülür. 
Daha önce örneklerine rastlansa da sanatçıların kokuyu farklı ve uygulanabilir bir sanat formu olarak desteklemeleri; ciddi anlamda 1980'li yıllarda olmuştur. Sanatçılar o dönemlerde ortaya çıkan beden, kamusal alan, kültürel kimlik, tüketicilik, cinsellik, çevrecilik gibi kavramları sorgularken, kokuyu ön plana çıkaran sanatsal üretimlerde bulunmuşlardır. Vücut kokularını yeniden yaratmış; galerilerde ve caddelerde kokuları dağıtarak, aromatik kültürel semboller kullanmışlardır. Ticari parfümleri kendilerine mal ederek ya da kendileri üreterek, kokulu organik malzemeleri kentsel bağlama yeniden dahil etmişlerdir.

Kokunun her tür sanatsal pratiğe dahil edilmesine yardımcı olmak adına, parfüm yapımının hammaddelerini, uzmanlıklarını, teknolojilerini ve büyük koku arşivlerini paylaşan ve yapay kokuların sentezlenmesi için koku alma araştırma laboratuvarlarının kapılarını sanatçılara açan sektör, sanatta alternatif projeler üretmeleri için sanatçıları teşvik etmiştir. İyileşen koşullar, sanatçıların daha fazla üretim yapabilmelerine olanak sağlamıştır. Koku sanatının gelişimi; duyuların, tarih, antropoloji, sosyoloji, feminizm ve kültürel çalışmalar gibi disiplinler arası perspektiflerin araştırmalarıyla doğrudan ilişkilidir. 1990'lı yıllarda koku alma sanatı üzerine üretimlerin arttığı görülmüştür. Koku üzerine çalışmaları olan eleștirmen Drobnic'e göre; “Koku alma sanatı, zorunlu olarak melez bir formdur. Sanatçı, kokuyu estetik bir deneyim olarak izole etmeye çalışsa bile, kullanımı teknoloji, mimari, yerleştirme veya performans gibi diğer faktörlere bağlıdır" diyerek kokuların diğer bazı yerleşik görsel sanat biçimleriyle kombinasyonları olduğunu savunmuştur (URL6). Drobnick, Koku alma sanatının üç ana çıkmazı olduğunu öne sürmekte ve bunları epistemolojik, ontolojik ve etik olarak sınıflandırmaktadır. Epistemolojik kokuların, yoğun, zorlayıcı ve duygusal olduğunu, aynı zamanda da tanınmaz, yeterince temsil edilemez ve teorileştirilmemiş olduğunu aktarırken, kokunun deneyimselliği ile anlamı arasında büyük bir uyumsuzluk olduğunu ifade ederken, kokuların, görsel, sonik veya metinsel modellere dayanan açıklamalardan kaçtığını, durumları kışkırttığını ve geleneksel epistemolojik yöntemlerle sınırlandırmalara meydan okuduğunu düşünür. Ontolojik kokuların, doğası gereği tahmin edilemez, gizemli, değişken ve kişiler üzerindeki etkilerinin de fizyolojik ve psikolojik düzeylerde dönüștürücü olabileceğini ifade eder. Üçüncü ve son çıkmaz olan etik, dış dünyanın küçük bir bölümünü inhalasyonla birlikte getirerek, kokuların çevre ve beden, ben ve diğerleri, doğa ve kültür arasındaki geleneksel ayrımları bozduğunu belirterek, nefes alarak duyumsanan kokunun, sorgulayan ve kabul edilen bilgi ve estetiğin yeniden değerlendirilmesini zorlaştırdığını belirtmektedir (URL7).

Çalışmalarında kokuyu kullanan sanatçıların, kokuları; uçuculuğu nedeniyle alımlayanı fiziksel olarak kokunun salındığı mekânda doğrudan meşgul etmesi, güçlü etkisiyle insanlar üzerinde kişisel duygusal çağrışımlar uyandırması, kimlik ve cinsellik gibi konularla ilgilenen sanatçılar için, duyumsanan canlılığının insanların temel bedensel işlevlerle yakın ilişki içerisinde olması gibi avantajlar sağlaması nedeniyle sanatsal çalışmalarında tercih ettikleri görülmektedir. Bunun yanı sıra bazı sanatçılar kokuyu, sergilenememesi, satılamaması ve muhafaza edilememesi gibi özelliklerinden dolayı tercih etmektedirler (URL8).

\section{Peter De Cupere'nin Kokulu Sanat Pratiği}

Peter De Cupere 1970 yılında Belçika'da doğmuştur. Güzel sanatlar eğitimi almış ve eğitim hayatını iki yüksek lisans derecesi ve bir doktora unvanı ile tamamlayarak, sanat eğilimini koku deneyimleri üzerine yoğunlaştırmıştır. Kendini "kokularla çalışan görsel sanatçı" olarak tanımlar. Görsel sanatlar alanındaki üretimlerinin yanı sıra; yazar ve akademisyen olan sanatçı Hasselt'deki (BE) PXL-MAD School of Arts'ta öğretim üyesi olarak çalışmaktadır. Akademisyen sanatçı ayrıca Senses Lab'da yakın duyuların, kokuların, tatların ve dokunmanın kullanımını aktaran dersler de vermektedir. Koku, tat ve dokunmanın sanat eseri için bir araç olarak kullanımını teşvik eden sanatçı, İngilizce Güzel Sanatlar Yüksek Lisans Programı Sanat Duygu Laboratuvarı'nın da kurucusudur. Sanatçının koku alma duyusu ile ilgili sosyal, çevresel ve kültürel bağlamlar üzerine ürettiği 700'den fazla eseri bulunmaktadır. Kokuların çağrışımsal etkisiyle görsel imgeleri birleştirerek, koku resimleri, sabun heykel ve resimler, koku enstalasyonları, performanslar, videolar vb. çalışmalar oluşturmaktadır (URL9).

Sanatçı, iki yıl boyunca kendi vücudundan alıp biriktirdiği kokularla imzaladığı Olfactory Art (Koku Sanatı) manifestosunu 2014 yılında yayınlamıștır. Manifestosunda İtalyan ressam Carlo Carra'dan ilham alan Cupere, Carlo Carra'nın manifestosundan bu yana kokunun görsel sanatlarda çok sık kullanılmadığını, atıflarda bulunulduğunu fakat tek başına neredeyse hiç varlık gösteremediğini 
belirtmektedir. Sanatçıların tam anlamıyla kokuyu, görsel sanatlarda kullanmalarının 20. yüzyılın sonlarına denk geldiğini ifade etmektedir.

Koku 2000'li yıllarda, bir araç olarak sanatçıların çalışmalarında değerli hale gelmiş ve tek başına bir ifade biçimi olarak kabul edilmiştir. Sanatçı, o yıllarda enstitüler, kuruluşlar ve çeşitli müzelerin koku sanatına, giderek artan bir şekilde yer verdiğini ve genç yeteneklerin eğitimlerine de bu ortamların olanak sağladığına işaret eder.

Sanatçı manifestosunu, kokuyu değerli kılmak ve dikkatleri kokunun üzerine çekmek için yazdığını söylemektedir. Kokunun da tıpkı fotoğraf, ses ve video gibi görsel sanatlara entegre edilmesi gerektiğini, böylece koku sanatının yeni bir sanat hareketi olarak kabul görebileceği ve sanatın izmlerine "Olfactism" olarak eklenebileceğini dile getirir. Olfaktism genel olarak kokunun bir araç ve işin bir parçasını oluşturan bir öge olarak, ayrıca kokunun kendisinin sanat yapıtına dönüşmesi fikri etrafında değerlendirilebilir. Sanatçı, kokunun bağlam olduğu veya bağlam sağladığı koku kavramları ve/veya sanat eserleriyle ilgili olduğu sürece, temsilinin mümkün olabileceğini iddia etmektedir. Cupere manifestoda Olfactism kavramını; Olfactionism ve Olfactorism olarak ikiye bölebileceğimizi, Olfactionism'in 'gerçek' ve 'eylem' kavramlarından hareket ettiğini, Olfactorism'de ise kokunun; aktör veya faktör olarak bulunabildiğini aktarır. Olfactionism'de gerçek eyleme teşvik ederken; eylem, bir kişiyi gerçek üzerine düşünmeye, hatta bir gerçeği kabul etmeye teşvik edebilir. Böylece gerçek üzerine düşünülebilir. Koku, gerçeği sorgulamak için kişiyi eyleme yönlendirir, belirli bir eylemin sonucu, gözlemi veya deneyimi olan gerçek de olabilir. Bu anlamda koku çalışma için bir bağlam oluşturur. Genel olarak, Olfactionism terimini esas olarak kokunun kendi içinde bağlam sağladığı, görsel ve/veya işitsel, dokunsal veya tatlandırıcı ile bir bağlama sahip olduğu sanat eserleri için kullanılmıştır. Koku, diğer duyularla ilişkili bir bağlama ulaşmak için çalışmanın kavramı olarak da kullanılabilir. Olfactorism terimi esas olarak, koku veya koku temelinde oluşan sanat eserlerinde, yalnızca renkler, şekiller, kompozisyonlar, kontrastlar, ışık veya karanlık ile kombinasyon halinde kullanılır. Koku faktörü işin merkezinde yer alır. Bağlam ise kokunun neyi uyandırdığı veya neyin deneyimlendiği ile ilgilidir. Olfactorism'de alımlayan, çevrenin, hayvanların, vücutların, bitkilerin vb. kokularını yeniden şekillendirip, koku dışında hiçbir şey kullanmadan koku bilincini yaratırken; Olfactionism'de, koku bilincinin yaratılması birtakım cihazlar ve başka yollarla da gerçekleştirilir. İçinde turizm kelimesinin gizlendiği Olfactourism kelimesi ise sanat dışı bir kullanımdadır. Örneğin aroma terapisi, koku reklamları, fonksiyonel kokular vb. için kullanılır. Cupere manifestosunda, koku alma sanatını koku enstalasyonları, koku resimleri, koku heykelleri, koku çizimleri, koku odaları, koku mimarisi, koku dansı gibi olasılıklarını sıralarken bu listenin bir sınırlama değil, serbestçe çoğaltılabileceğine işaret eder. Cupere'ye göre önemli olan kokunun işin önemli bir parçası olması ve birlikte Olfactizm olarak nitelendirilmesidir (URL10).

Sanatçıya göre Olfaktizm' de koku; tek başına ya da işe katkısı bulunduğu sürece çalışmada varlık gösterir ve bir sınırlama yoktur. Her şey koku olabilir; kokular güzel de olabilir kötü de. Koku seçimi sanatsal çalışmayla tutarlı olduğu, çalışmanın anlamı, çözümlenmesi ve deneyimine katkıda bulunduğu sürece özgürlüktür.

Sanatçı manifestosunun son bölümünü şu cümlelerle bitirmiştir;

Bu manifesto, tüm sanatçıları koku deneyine girmeye çağırıyor.

Bu manifesto, tüm küratörleri, müze yönetmenlerini, sergi yapımcılarını ve organizatörleri daha fazla koku alma sanatına ilgi göstermeye çağırıyor.

Bu manifesto, tüm izleyicileri bir koku alma sanat eseri deneyimlediklerinde burunlarının ötesine bakmaya, işin bağlamında hareketsiz durmaya ve kokunun ortam olarak işlevi hakkında düşünmeye çağırıyor.

Bu manifesto herkesi daha sert kokmaya çağırıyor! (URL11) 


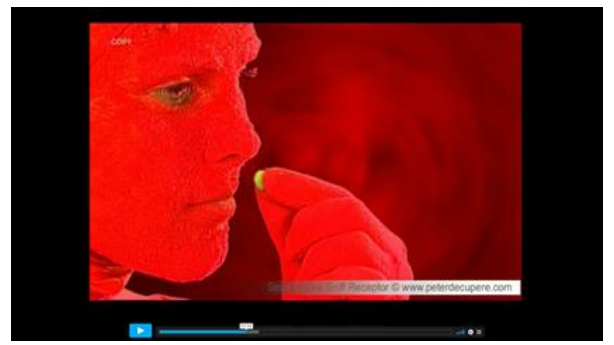

Görsel 1. Koku Film-Koklama Alıcısı 2003 (https://vimeo.com/2876405)

Peter de Cupere'nin kokuyu deneysel olarak çektiği Koklama Alıcısı (Görsel 1) adlı 12 dakikadan oluşan film sanatçının kokuyu taşıdığı mecralardan biridir. Sanatçı 2009'da verdiği bir röportajında bu projenin uzun zaman aldığını, pahalı bir proje olduğunu ama sanat dünyasında koku ile ilgili çok az deneysel çalışma olduğu için, bu çalışmanın bir gereklilik olduğunu söyler. Yaptığı çalışmayı diğer sanatçıları kokuyla çalışmaya teşvik için bir meydan okuma gibi görür. New Media'ya yakın ilgi duyan sanatçı, kariyeri için "Koku" filmini çekmesinin mantıklı bir adım olduğunu düşünür. 2D, 3D, hareketli görüntüye kadar çeşitli programlarla ilgilenen sanatçı, internet sitelerini kendisi oluşturur. Koklama Alıcısı filmine başlamadan önce akşam derslerinde kendini film sanatına adadığını, bunu sadece koku filmi çekmek için değil, aynı zamanda bir sanatçı olarak böyle bir donanımın kendisi için bir zorunluluk olduğunu varsaymıştır (URL12).
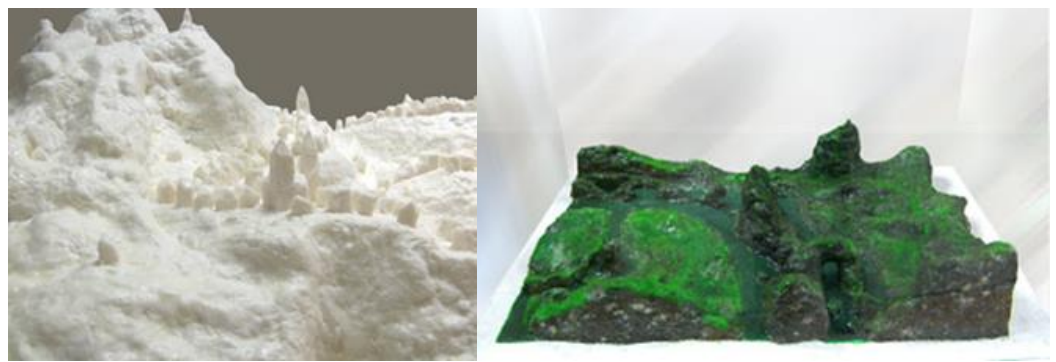

Görsel 2: Soap City ve Soap Landscape heykelleri, karışık teknik 2008

(http://www.peterdecupere.net/index.php?option=com_content\&view=article\&id=23:soapcitiesand-soaplandscapes-in-true-love\&catid=1:exhibition-news\&Itemid=98)

Cupere'nin Soap City heykeli (Görsel 2) \%50 sabun ve \%50 topraktan yapılmış şehir ve manzara görüntüleridir. Sürecin önemli olduğu bu çalışmada; Sanatçı heykelinde hava, sıcaklık ve nemin reaksiyona girmesi ve küçük parlak kristaller oluşturmasını amaçlamaktadır. Çalışmaya sabunla reaksiyona girerek terlemesine neden olan bir üründe eklemiştir. Birkaç yll sonra planlanan tepki çözümlenecek ve şehirlerin ve manzaraların üzerinde küçük bir toz kalacaktır. Sabun heykellerde; beyaz şehir yoğun nane kokarken, yeşil doğal peyzajda yoğun çimen kokusu hakimdir. Sabun heykeller pleksi bir malzemenin içinde sunulmasına rağmen çok yoğun kokmaktadırlar (URL13).
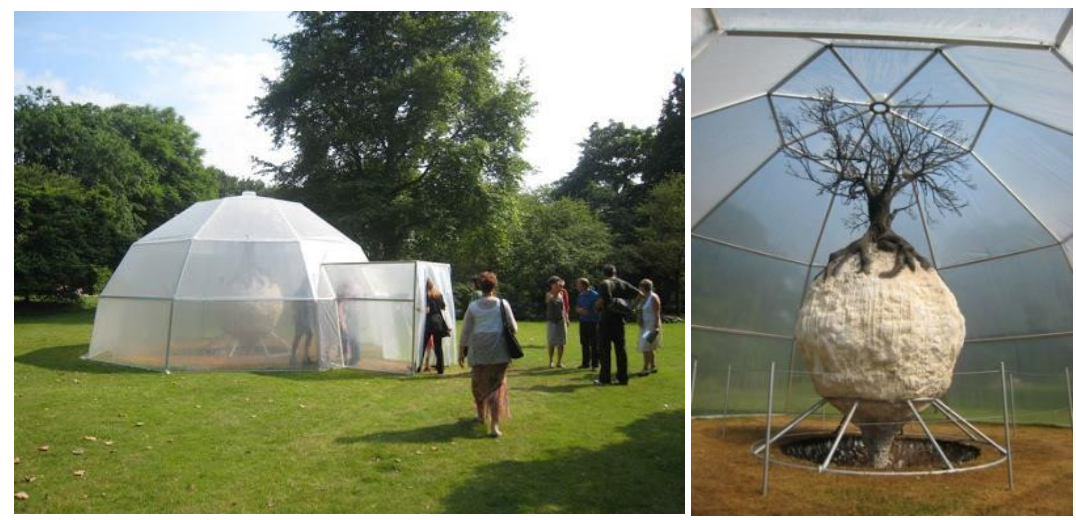

Görsel 3. Ağaç Virüsü, 7x3,70 2008

(http://www.peterdecupere.net/index.php?option=com_content\&view=article\&id=16:exoten\&cati $\mathrm{d}=1$ :exhibition-news\&Itemid=98) 
Sanatçı Ağaç Virüsü (Görsel 3) çalışmasında; yaklaşılk 7 metre'ye 3,70 metre ölçülerinde Eskimo evlerine benzer naylon bir çadır içerisinde, toprak bir çukurun üzerinde asılı duran beyaz bir topun üzerine, kuru bir ağaç yerleştirmiştir. Ağacın üzerinde (Görsel 4) PTDB ağaç virüsleri büyür. Çadırın içine giren izleyiciler yoğun nane ve karabiber kokusuyla karş̧laşır. Etkileşime geçtiklerinde insanları ağlatacak kadar güçlü bu koku karşısında izleyicilerin oldukça zorlandığı bir deneyim yaşanır (URL14).

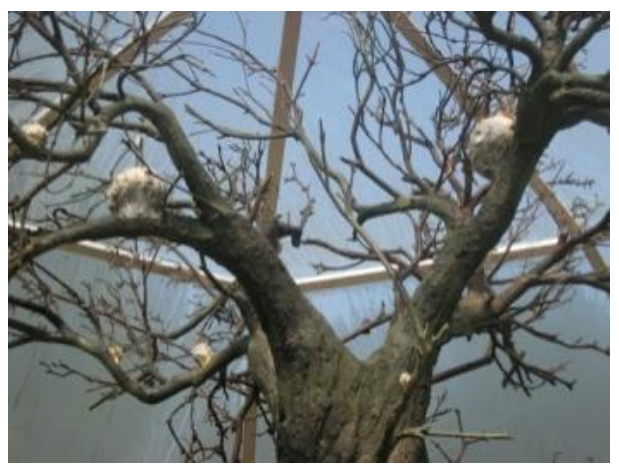

Görsel 4. Ağaç Virüsü, 2008, Detay

(http://www.peterdecupere.net/index.php?option=com_content\&view=article\&id=26:exoten\&cati $\mathrm{d}=14$ :featuredartworks)

Bu projenin arkasındaki fikir, yarı parazitler hakkında bir düşüncedir. Cupere "Yarı parazitin hayatta kalması için güneşin fotosentezine ihtiyacı var. Enstalasyonda, moleküllerin birbiriyle reaksiyona girmesi için güneşin ısısına da ihtiyacı var " (URL15) der.

Sanatçı kokulu bir enstalasyona girildiğinde saklanılamayacağını ve görüp düşünmenin ötesinde, çalışmanın izleyiciyi nasıl etkileyebileceğini hissetmesini de ister. Kokuyla; evrensel, herkes tarafından anlaşllabilecek işler yapabileceğini, ancak bunun yine de her zaman kişisel bir yönünün olacağını, kokunun çalışmalarına, görmekten daha samimi ve öznel başka bir boyut kattığını ifade eder (URL16). Cupere, kokunun duyumsandığı anda bizi nasıl anlık olarak savunmasız ve kontrolden çıkmış bıraktığına vurgu yapar.

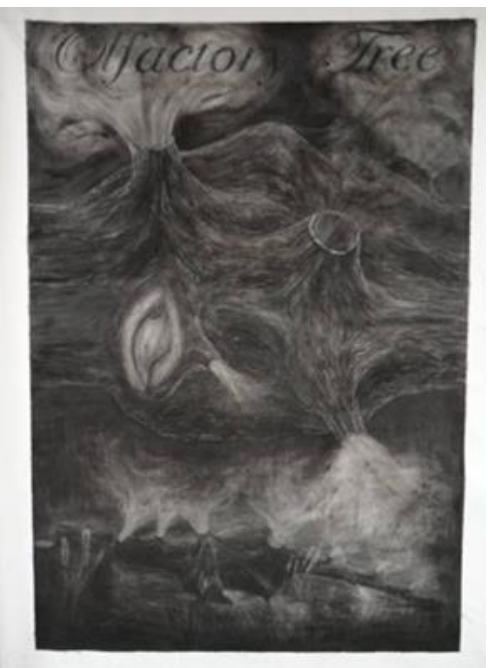

Görsel 5: Olfactory Tree Drawing, kömür çizim, epoksi, poliüretan, 2010 Pocketroom Antwerp Belgium (https://www.saatchiart.com/account/artworks/98361)

Çalışmalarında doğa olayları ve doğada yer alan varlıklardan da esinlenen, doğa da meydana gelen olguları farklı malzemelerin katkı ve etkileri ile ele alan sanatçı epoksi ve poliüretan bileşenlerinden oluşan Koku Ağacı çiziminde (Görsel 5), izleyiciye, doğada günlük yaşam içinde her gün karşılaştığımız ve kendi farklı organik yapılarına bağlı olarak duyularımıza hitap eden reçine kokularını ele alarak ağacın içine bakmak suretiyle doğayı koklayabileceklerini söyler. Sanatçı 
çalışmasında; Ahşap, sedir, çam, mantar, çimen kokularını salgılayarak geçmiş deneyimlerimize ilişkin koku duyularımızı harekete geçirmeyi amaçlamıștır (URL17).

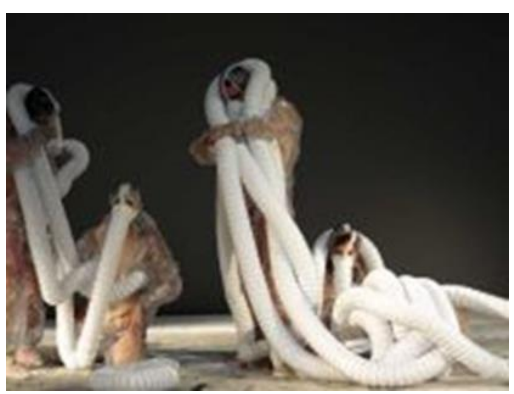

Görsel 6. “Ter” 2010

(http://www.peterdecupere.net/index.php?option=com_content\&view=article\&id=94:sweat\&catid $=20$ :news)

Peter De Cupere, 2010 yılında, Jan Fabre tarafından koreografisi yapılan ve beş dansçının terinin toplandığı Ter (Görsel 6) adlı performansını gerçekleştirir. İnsan vücudunun mekanik bir unsuru olarak ele alınan ter olgusu sadece bireyin kendi fizyolojik yapısı sonucu ortaya çıkan bir eylem olmanın dışında beslenme ve benzeri faaliyetler sonucunda ortaya çıkan farklı reaksiyonların sonucuna bağlı olarak değişkenlik gösterebilmektedir. Konuyla ilgili olarak Ozan;

Terleme, aslında vücudumuzun soğutma sisteminin devreye girdiğinin göstergesi. Tıpkı bir araba motorunda olduğu gibi, çalışan ve ısınan elemanlar soğumaya ihtiyaç duyar. Basit bir fizik kuralı olarak sıvı buhara dönüșürken, bir miktar ısıyı da ortamdan alarak buhar yolculuğuna çıkar. Ter üretmede ciddi sorunlar yaşayanlarda, yani genel olarak belli bir yaşın üstündeki insanlarda, özellikle yaz dönemlerinde daha çok can kaybı yaşanmasının nedenlerinden biri de, bu soğutma sisteminin sağlıklı üretim yapamaması ve dolayısılyla ısınmanın önüne geçememesidir. Tuzlu ter sıvısı içinde çoğunlukla su vardır, ancak suyun yanı sıra başka malzemelerde mevcuttur. Bunlar kloridler gibi bazı katı maddelerin erimiş halleridir. Ter sıvısı içinde vücut yapımıza göre değişen oranda ve miktarda üre de bulunur... Şaşırtıcı bir şekilde aslında ter, oldukça kokusuz bir sıvıdır; yüzde 99' u sudan oluşur. Koku bu sıvının bakterilerle ilişkiye girmesi halinde ortaya çıkar. Evet, cildimiz, aslında bir bakteri yuvasıdır. Vücudumuzun en sıcak bölgelerinden koltukaltı veya apışarası gibi yerlerde az önce bahsettiğim soğutma faaliyeti gerçekleştiğinde, nemli ve sıcak bölgeleri en elverişli yaşam alanları olarak seçen bakteriler, terin içindeki moleküllerle beslenir ve elbette atık faaliyetinde bulunur. Cook basit bir benzetme yapmamız gerekirse, apokrin bezemizin soğutma amaçlı salgısını yiyen sevgili bakterilerimiz, def-i tabiilerini de hemen oracıta giderirler. Koku tahmin edebileceğiniz gibi tam da bu anda ortaya çıkar (Ozan, 2020: 99,100,101).

Eylemden önce sanatçı, dansçılara farklı yemekler yedirir. Sanatçının amacı dansçıların terini alıp damıtmaktır. Plastikten yapılmış kostümler giyen dansçıların performans sonucu terleri toplanarak duvara püskürtülür ve bir cam kutu ile korunur. Daha sonra izleyiciler, cam altında video olarak gösterilen performansı izlerken, küçük bir delikten ter kokusunu deneyimleyebilmektedirler (URL18).
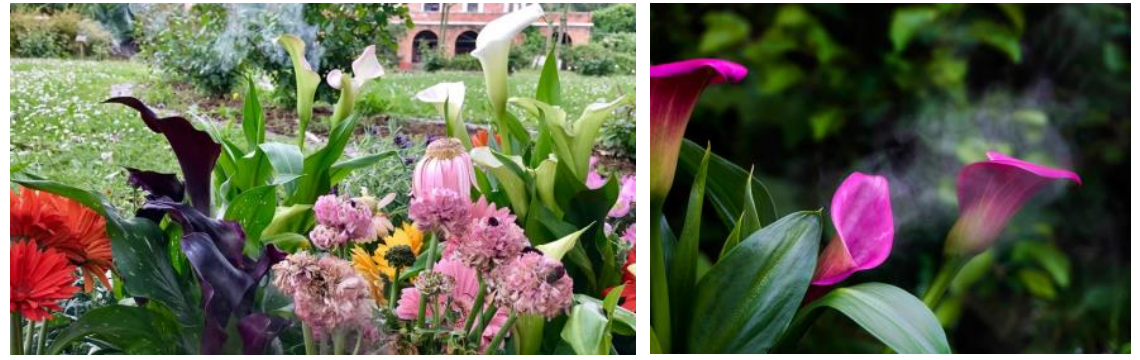

Görsel 7. Smoke Flowers 2017

(2017http://www.peterdecupere.net/index.php?option=com_content\&view=article\&id=187:smok e-flowers-in-venice \&catid=1:exhibition-news\&Itemid=98)

Sanatçının 2017'de Sadakichi ödülüne layık görülen (Smoke Flowers) Duman Çiçekleri (Görsel 7) çalışması modern endüstri ve çağdaş yaşamın, doğa üzerinde yarattı̆̆ı olumsuzluklara bir gönderme niteliği taşır. Gerçek çiçekleri kullandığı çalışmasında, çiçeklerin kirli hava kokusu yaymaları 
alımlayıcı açısından şiirsel olduğu kadar ironik ve dokunaklıdır. Çiçeklerden yayılan kirli hava IFF araştırma laboratuvarı tarafından oluşturulmuştur. Çiçeklerden dumanla birlikte yayılan kokuyu deneyimlemek üzere yaklaşarak koklayan insanlar, çiçeklerden beklenen hoş koku beklentisinin yerine, kötü kokuyla karşılaştıklarında yaşadıkları farkındalıkla doğa üzerine yeniden düşünme ve sorgulama sürecine girer.

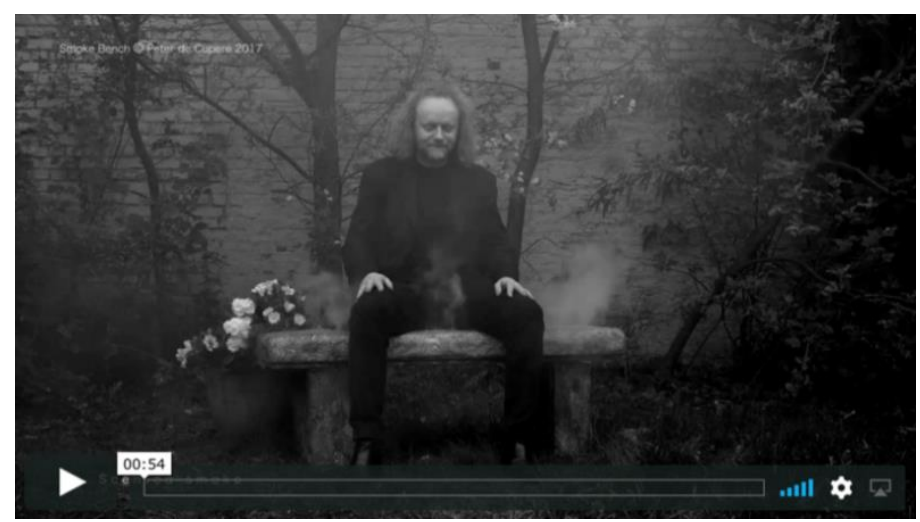

Görsel 8. Koşulların Kokusu 2017

(http://www.peterdecupere.net/index.php?option=com_content\&view=article\&id=194:sc ents-ofconditions\&catid=20:news)

Koşulların Kokusu (Görsel 8) çalışması sanatçının hassas mekanizmalarla oluşturup mekan içine yerleştirdiği üç banktan oluşur. Hiçbir şekilde zehirli olmayan, buhar bazlı dumanın eşlik ettiği çalışmada; ahşaptan yapılan bank, ağaç, çimen ve çiçek kokularından oluşur ve izleyiciyi katıksız doğanın kokusunu almaya davet eder. Cupere, günümüz kent insanının kentsel alanlarda maruz kaldığı kirli havadan kaynaklanan deneyimin yerine; zamana dair nostaljik bir esinlenmeyle, gönderme yaptığı, doğanın bize sunduğu temiz ve doğal kokulu bir deneyimi mümkün kılmıştır. Pastoral bir manzarada, sisi çağrıştıran dumanlı atmosferik görüntüsüyle gelen kokunun, hatırlamanın ötesinde, alımlayana geçmişte yaşadığı deneyimleriyle bağlantı kurdurtarak yeni deneyimlerin kapılarını araladığı gibi, kișisel bir sıfırlama olarak da ilham verici kabul edilebilir. Taştan yapılan ikinci bankta, endüstriyel kirliliğin yarattığı kokular dumanla ortama salınır. Bahçenin zarif ortamıyla zıtlık oluşturan kokunun yarattı̆̆ deneyim bir alarm etkisi yaratmıştır denilebilir. Son bank ise beyaz rengiyle, genellikle yakın zamanda yaşamını yitirmiş insan bedenleriyle ilişkili bir koku bulutu içinde izleyiciyi sarmalar. Cupere, günlük hayatta çok da üzerinde durulmayan ölüm olgusu üzerine düşünmeyi önermiş ve kokunun çarpıcı etkisiyle bu düşünceyi radikal bir şekilde sunmuştur (URL19).
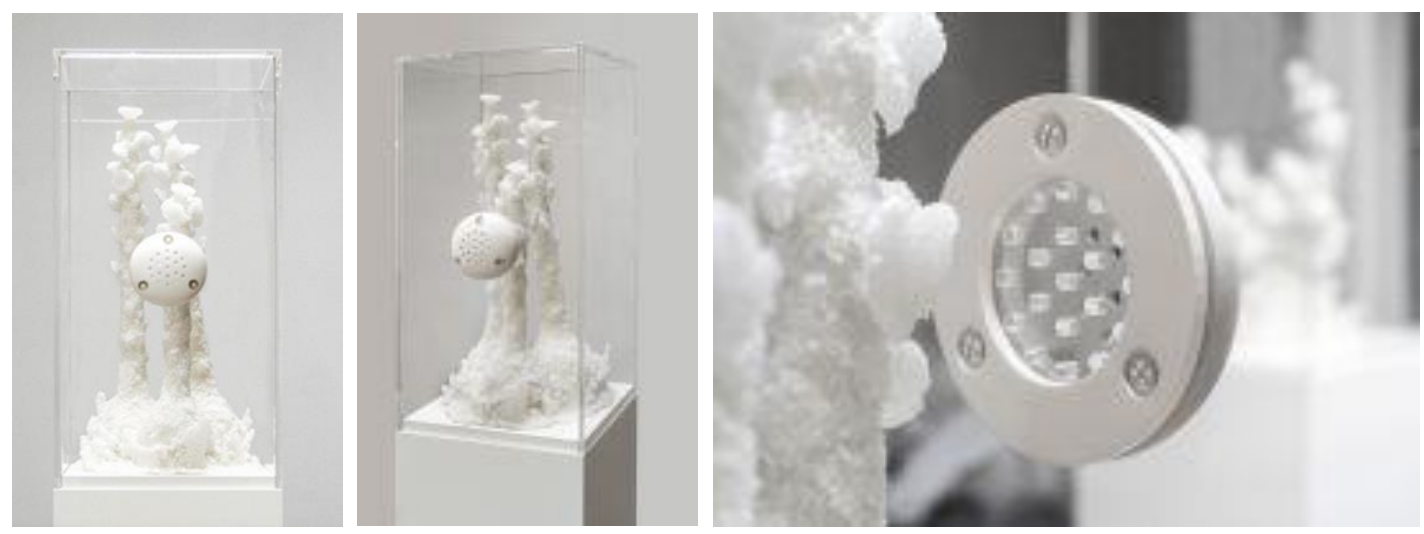

Görsel 9. Salt Flower, Tuz kristalleri 2018

(http://www.peterdecupere.net/index.php?option=com_content\&view=article\&id=191:saltflowers-in-ecce-homo\&catid=1:exhibition-news\&Itemid=98)

Salt Flower (Görsel 9) çalışması ile Peter de Cupere, yükselen deniz seviyesinin endişe veren durumunu sorgular. Tatlı suyun tuzlu suya dönüştüğüne ve biyolojik çeşitliliğin yok olma tehlikesiyle karşı karşıya kaldığına dikkat çekerken, bu duruma özgü, hayatta kalmanın ütopik bir 
yolunu arar. Ardından Kuzey ve Güney Kutbu'nda kaybolan beyaz buz örtüleri ve beyaz tuz arasındaki analojik ilişkiyi çalışmalarına taşıyarak, üç boyutlu çalışmalarında; bitki, meyve, sebze ve çiçeklerle beyaz tuz doğasını sunar. Çalışmalarının her birinin kendine has kokusu vardır. Çalışmalarının gücü, sadece çiçeklerin görsel başarısından değil, koku seçiminden de geldiği gibi, görsel olarak çiçekler estetik ve bakir beyaz taneciklerden oluşur. Sanatçı, "bir şeyleri nasıl deneyimliyoruz" sorusu etrafında ve izleyicinin algısı üzerine yoğunlaşarak çalışmalarında tuz tanecikleriyle benzerliği sebebiyle cam malzemeyi kullanmıştır. Sanatçı çalışmada; alımlayan açısından görülen şeyin ne olduğu ve gözlemlenen şeyin ne olduğunu bilmenin ne kadar önem teşkil ettiği üzerine dikkat çekmek istemiştir.

Sanatçı, 'ne verirsen onu alırsın' fikriyle çevre politikaları ve ekonomik yapıya gönderme yapar, kendi eliyle sentetik ürünler ve yapay kokular üreten insanı doğayla ilişkisi üzerine düşünmeye, sorgulamaya çağırır (URL20).

\section{Sonuç}

Kokunun estetik ve sanatsal ifadesinin Peter de Cupere özelinde incelendiği bu çalışmada, kokunun hafızayla güçlü bir ilişkisi olduğu görülmüştür. Sanatçı, koku enstalasyonları, koku resimleri, koku heykelleri, koku çizimleri, koku odaları, koku mimarisi, koku performansları gibi çeşitli mecralara taşıdığı kokuyla açılımlar yapmış ve bu yelpazenin daha da genişleyebileceği konusundaki tavsiyeleri sanatçı röportajlarında da yer almıştır. Cupere'nin çalışmalarında kokunun kimi zaman yardımcı bir öge olarak yer aldığı kimi zamansa tek başına çalışmanın kendisini oluşturduğu görülmüştür.

Kendini kokularla çalışan görsel sanatçı olarak tanımlayan Cupere'nin çalışmalarında, kokuların uyandırdığı kişisel ve çağrışımsal etkisini görsel imgelerle yan yana getirerek, salt görmenin ve koklamanın ötesinde bir tür meta-duyusal deneyim yarattığı görülmüştür. Yapılan araştırmada Sanat eserinin sadece görme duyuları üzerinden değerlendirilemeyeceği anlaşılmış, geçmiş yaşantılarımızda karşılaştığımız sıradan veya olağanüstü durumlar sonucunda, belleğimizde yer edinen koku, tat, dokunma gibi diğer duyularla da değerlendirilmesi gerekliliği ortaya çıkmıştır. Çalışma kapsamında incelenen Peter De Cupere çalışmalarında; biçimsel deneyimlerin veya nesnelerin kendine özgü biçimlerinin koku duyusuyla birlikte belleğimize nasıl yansıdığını, kokuların bizde açığa çıkardığı duygusal farkındalıkları inceleyerek, sanat eseri üzerinden ortaya çıkarılmasını hedeflemiştir. Sanatçı sadece biçimsel olarak değil duyusal olarak ta izleyiciyi kendi öz benliği ile buluşturmayı ve aynı atmosfer içinde, kendi deneyimleri ile yüzleştirmeyi amaçlamaktadır. Böylece sanat eserinin sınırsız kaynak olanaklarının, sanatçılar tarafından nasıl kullanılabileceğine dair örnekleri ile yeni yaklaşımlara yelken açılmasına olanak sağlamaktadır. Sanatçının 700'ün üzerinde çeşitli mecralarda ürettiği koku çalışmalarıyla genellikle göz ardı edilen bu duyunun yarattığı etki için alternatif yollar aradığı ve aramaya da devam ettiği kaynaklarda görülmüştür.

Örneklem çalışmaların analizi sonucunda; kokunun izleyiciyi savunmasız bir şekilde, derinlemesine çalışmalara dahil ettiği ve kişiye özel deneyimler yarattığı sonucuna varılmıştır. Koku yoluyla çalışmaların içeriğinin izleyiciye daha etkili bir biçimde aktarıldığı görülmüştür. Teknolojik ve bilimsel gelişmelerin ışı̆̆ında koku laboratuvarları sayesinde kokunun erişimi kolaylaşmış ve böylece sanatçılar çalışmalarında kullanmak istedikleri kokuya rahatlıkla ulaşabilmişlerdir. Ağaç Virüsü (Görsel 3) ve Duman Çiçekleri (Görsel 7) çalışmalarında olduğu gibi mekânda kokunun alımlayan tarafından sürekli olarak aynı oranda aynı şiddette duyumsanabilmesi için sergi stratejilerinin sağlanması koşuluyla çalışmanın amacına ulaşabileceği düşünülmüștür. Ağaç virüsü (Görsel 3) çalışmasındaki yoğun nane ve karabiber kokusuna maruz kalan alımlayanın farklı zamanlarda kokuyu aynı şiddetle hissetmesi ve gözlerinden yaşlar gelmesi bu stratejiye bir örnek oluşturmaktadır. Bu noktada küratörlerin ve sergi yöneticilerinin bu atmosferin oluşturulabilmesi için iş birliği içinde olmaları şarttır. Peter de Cupere'nin çalışmalarında kokuyu merkeze aldığı ve bu yolla izleyiciye farklı duyusal-duygusal deneyimler yarattığı, buradan hareketle de başka sanatçılara ilham veren ve bu sanatçıların yapıtlarında kokuyu kullanımlarını teşvik eden öncü bir sanatçı olduğu sonucuna varılmıştır. Sanatçılar tarafından yaygın olarak kullanılmayan koku sanatının gelişen bir mecra olarak araştırmacılar için, yeni yöntemler ve farklı bakış açılarıyla araştırmaya son derece açık olduğu görülmüştür. 


\section{Kaynakça}

Aristotales. (2011). Ruh Üzerine. Ankara: Birleşik Dağılım.

Causse, J. G. (2019). Renklerin Şaşırtıcı Gücü. İstanbul: Pegasus Yayıncllık.

Constance Classen, David Howes, \& Antony Synnott. (2003). Aroma, The cultural history of smell. London and New york: British Library.

Hopkins, D. (2018). Modern Sanattan Sonra (s. 287). içinde Hayalperest yayınevi.

Mercier, L. S. (2004). Paris Tablosu. İstanbul: İthaki Yayınları.

Muller, C. (2018). An Overview Of olfactory art. Nez , 99.

Ozan, V. (2020). Kokular Kitabı. İstanbul : Everest Yayınları.

Ruckel, T. S. (2006). The scent of a new world novel:translating the olfactory language of Faulkner and Garcia Marquez. Mississippi: Louisiana State University and Agriculturaland Mechanical Collage.

Solay, L. (2012). Scent in Contemporaray Art: An Investigation Into Challenges and Exhibition Strategies. Master Thesis. Laselle College of the Arts Singapore. Goldsmiths College, University of London

\section{İnternet Kaynakları}

URL1:Stafford, T. (2014), Dergi - Kokular Neden Anıları Hatırlatır, 02.01 .2021 tarihinde https://www.bbc.com/turkce/ozeldosyalar/2014/11/141127_vert_fut_koku_ve_anilar adresinden alınmıştır.

URL2:TheSmellReport,26.12.2020tarihindehttp://www.sirc.org/publik/smell_culture.html\#: :text =Western\%20cultures,the\%2018th\%20an\%20d\%2019th\%20centuries adresinden alınmıştır.

URL3: Art and Scent: Interpreting the Olfactory Arts, 25.12 .2020 tarihinde https://www.larryshiner.com/art-and-scent adresinden alınmıştır.

URL4:Vroon,P.(1997),SmellTheSecretSeducer, 26.12.2020 tarihinde https://archive.nytimes.com adresinden alınmıştır.

URL5: Shiner, L. 03.01.2021 tarihinde https://www.larryshiner.com/art-and-scent adresinden alınmıştır.

URL6:Drobnick,J.(2015)03.01.2021tarihindehttps://static1.squarespace.com/static/59ac8904299 4caa10199036a/t/59e5663b8fd4d2075ffd9707/1508206146857/smell_hybrid_art+2.pdf adresinden alınmıştır.

URL7:Drobnick,J.(2015)03.01.2021tarihindehttps://static1.squarespace.com/static/59ac8904299 4caa10199036a/t/59e5663b8fd4d2075ffd9707/1508206146857/smell_hybrid_art+2.pdf adresinden alınmıştır.

URL8: Shiner, L. 03.01.2021 tarihinde https://www.larryshiner.com/art-and-scent adresinden alınmıştır.

URL9:02.12.2020tarihindehttp://www.artandolfactionawards.org/2018overview/smokeflowers/ adresinden alınmıştır.

URL10: Cupere, P. 05.12.2020 tarihinde http://www.olfactoryartmanifest.com/en/ adresinden alınmıştır. 
URL11: 04.12.2020 tarinde https://mindmarrow.com/2017/10/repository-210-peter-de-cuperes20-year-scent-art-survey-book-and-the-quest-to-manifest/ adresinden alınmıştır.

URL12: 25.12.2020 tarihinde http://hildevancanneyt.blogspot.com/2009/08/interview-met-peterde-cupere.html adresinden alınmıştır.

URL13:07.01.2021tarihindehttp://www.peterdecupere.net/index.php?option=com_content\&view =article\&id=23:soapcities-and-soaplandscapes-in-true-love\&catid=1:exhibitionnews\&Itemid=98 adresinden alınmıștır.

URL14: 17.12.2020 tarihinde https://www.nytimes.com/2015/04/07/science/art-for-theknowing-nose.html adresinden alınmıştır.

URL15:21.12.2020tarihindehttp://www.peterdecupere.net/index.php?option=com_content\&view =article\&id=194: scents-of-conditions\&catid=20:news adresinden alınmıştır.

URL16:16.12.2020tarihindehttp://www.peterdecupere.net/index.php?option=com_content\&view $=$ article\&id=26: exoten\&catid=14:featuredartworks adresinden alınmıştır.

URL17:28.12.2020tarihindehttp://www.peterdecupere.net/images/stories/exhibitions/2017/ecc ehomo/Salft-Flowers-Ecce-Homo-02.jpg adresinden alınmıştır.

URL18: 04.01.2021 tarihinde https://scentartnet.tumblr.com/adresinden alınmıştır.

URL19: 19.12 .2020 tarihinde https://inimitablee.wordpress.com/2014/12/12/smelly-artinstallation-that-made-visitors-cry/ adresinden alınmıştır.

URL20: 20.01.2021tarihinde https://www.saatchiart.com/account/artworks/98361 adresinden alınmıștır.

\section{Extended Abstract}

For humans, the sense of smell is active before sight, hearing and even touch; it can be exemplified by a newborn baby first contacting the mother through scent. Affecting people at physical, psychological and social levels, smell has a very important place in the senses in this respect. It has been observed that the sense of smell is more developed compared to other senses when it comes to the ability of responsing to the chemicals around. Just as every healthy person senses all the smells around them when they breathe, the expressions of people who have lost their sense of smell show that they cannot enjoy the food and many things in life. While the sense of smell is critically important when evaluated in terms of the quality of human life, it is also in a crucial position when judged in relation to memory and memories. The close relationship of the powerful effect of the sense of smell and its close relationship with the memory and the situation that evokes memories are strikingly revealed in Marcel Proust's novel In Search of Lost Time, published in 1913-1927, and this situation was later known as the Proust effect in the literature. The strong relationship of scent with memories has attracted the attention of artists who create in the field of visual arts, and scent has begun to take its place in visual arts as a new means of expression for artists seeking alternative ways in their production. In this study, based on the use of scent as a means of expression in visual arts; the works of academic artist Peter de Cupere, between 2003-2018, who defines himself as a visual artist working with scents, were discussed. In his fragrance works, which the artist brought together with various media such as painting, sculpture, installation, video, performance, answers were sought through the analysis of the work to the questions such as how the fragrance contributes to the work of art and how it affects the audience, how the relationship with memory and memories occurs. The literature on the subject has been reviewed, and it is thought that the phenomenon of fragrance, which is examined through the work of the artist in terms of introducing new mediums to the field, will contribute to the field due to the lack of sufficient resources on the art of scent in Turkish resources. According to the research, it has been observed that the art of fragrance creates new areas of experience in terms of the receptor and is in close relationship with memory. In the study, document analysis method was used, the literature was examined, and the content analysis of the data obtained was made in the light of the artist's own website and the interviews. The aesthetic and artistic expression of the scent have been studied especially through the works of Peter de Cupere. The artist's suggestions about the scent installations, paintings, sculptures, scent drawings, fragrance rooms, fragrance architecture, and fragrance performances were also included in the artist's interviews. It has been observed in Cupere's works that he creates a kind of meta-sensory experience beyond just seeing and smelling, by juxtaposing the personal and associative effect of scents with visual images. In the study, it 
was understood that the work of art could not be evaluated only on the sense of sight, and as a result of the ordinary or extraordinary situations we encountered in our past lives, it was revealed that it should be evaluated with other senses such as smell, taste and touch. In the study, by using the works of Peter De Cupere in which scent is used as a means of expression, it is aimed to reveal how the unique forms of formal experiences or objects are reflected in our memory together with the sense of smell and the emotional awareness that scents help us expose. It has been observed that the artist aims to bring the audience together with their own self and to confront them with their own experiences in the same atmosphere, not only formally but also sensually. In line with the data obtained, it is clear that Cupere has produced works in many disciplines by using unlimited resources and offers new approaches to how these methods can be used by other artists. It is seen in his works that the artist is looking for alternative ways for the effect of this sense, which is often overlooked with his scent works he has produced in more than 700 different media. 